\title{
THE EVALUATION STUDIES OF KAMPUNG KB IN CENTRAL JAVA
}

\author{
Arri Handayani ${ }^{1}$, Najib ${ }^{2}$, Sukma Nur Ardini ${ }^{1 *}$, Padmi Dhyah Yulianti ${ }^{1}$ \\ 1 Universitas PGRI Semarang, Semarang 50232, Indonesia \\ ${ }^{2}$ BKKBN Provinsi Jawa Tengah, Semarang 50139, Indonesia \\ *) E-mail: sukmanurardini27@gmail.com
}

\begin{abstract}
Kampung KB becomes one of the strategic innovations to implement the priority activities of the KKBPK Program as an effort to achieve the target of the Development of Population and Family Planning Control (Pembangunan Bidang Pengendalian Penduduk dan Keluarga Berencana). The data collected through a qualitative approach. The instrument used was an interview guide to conduct an in-depth interview with various participants. The location of the study was chosen by purposive technique; Magelang, Sukoharjo, and Temanggung. The data are grouping into input, process, and output. Related to the input, the establishment of Kampung KB is already by the guidelines, people's participation is quite good, but the support of facilities and infrastructure is still at a minimum level. About the process, the consuming data came from 2015, coaching and movement are not regularly scheduled. The last relates to the output, that is Kampung KB activities such as Tri Bina (BKB, BKR, $B K L)$, UPPKS, PIK-R, learning guidance, and libraries, while activities from across sectors include drainage, privies, corn seedling, home industry training, duck livestock training, and infrastructure improvements. However, the improvement of the KKBPK program achievements has not been completed, even though it changes the social welfare.
\end{abstract}

Keywords: input, kampung KB, output, process

\section{Studi Evaluasi Kampung KB di Jawa Tengah}

\begin{abstract}
Abstrak
Kampung KB menjadi salah satu inovasi strategis untuk dapat mengimplementasikan kegiatankegiatan prioritas Program KKBPK sebagai upaya pencapaian target Pembangunan Bidang Pengendalian Penduduk dan Keluarga Berencana. Pengumpulan data melalui pendekatan kualitatif. Instrumen yang digunakan pedoman wawancara untuk melakukan wawancara mendalam dengan berbagai informan. Lokasi penelitian dipilih secara purposif yaitu kota magelang, kabupaten sukoharjo, dan kabupaten temanggung. Berdasarkan hasil penelitian data pendekatan kualitatif, terdapat tiga kelompok yang meliputi input, proses, output. Pertama, berkaitan dengan input yakni pembentukan wilayah kampung KB sudah sesuai pedoman, partisipasi masyarakat cukup baik, namun dukungan sarana dan prasarana masih sangat minim. Kedua, berkaitan dengan proses yakni data, pembinaan dan penggerakan belum terjadwal secara rutin. Ketiga, berkaitan dengan output yakni bentuk kegiatan dikampung KB diantaranya Tri Bina (BKB, BKR, BKL), UPPKS, PIK-R, bimbingan belajar dan perpustakaan pintar, sedangkan kegiatan dari lintas sektor diantaranya meliputi drainase, jambanisasi, pembibitan jagung, bank sampah, pelatihan home industry, pelatihan ternak bebek, dan perbaikan infrastruktur. Namun, peningkatan capaian program KKBPK belum sepenuhnya terpenuhi, walaupun membawa sedikit perubahan pada kesejahteraan masyarakat.
\end{abstract}

Kata kunci: input, kampung KB, output, proses

\section{INTRODUCTION}

The National Population and Family Planning Board or Badan Kependudukan dan Keluarga Berencana Nasional (BKKBN) is one of the non-ministry institutions that have the mandate to realize the Government's Priority Development Agenda (Nawacita) from 2015 to 2019, especially on the third Priority Agenda which about "Building Indonesia from the Slum 
Area by Strengthening the Regions and Villages on the Framework of Unity States", the fifth Priority Agenda is "Improving the Quality of Human Life in Indonesia", also the eighth Priority Agenda is "Nation Character Revolution" through Population and Family Planning Development. To realize those priorities agenda, BKKBN should be able to implement the National Development Strategy of 2015-2019 (on the National Development Dimension) by a focus on the Health Development Dimension and Mental / Character (Mental Revolution) to be integrated into the Population Programs, Family Planning and Family Development or Keluarga Berencana dan Pembangunan Keluarga (KKBPK).

In the appendix I regulation of the head of the population and national planning family No. 87/KEP/G3/2014 dated April 1st, 2014 concerning the guidelines of implementing the field line mobilization Program, family planning and family Development year 2014 mentioned that the success of KKBPK program is not separated from the actualization or movement of real action program KKBPK at the field line level. It is further said that the special purpose of the movement of KKBPK Program is 1) improving the understanding and awareness of the family and society in the program KKBPK; 2 ) improving the ability of the managers of KKBPK at the district level in the movement of KKBPK program in the field. With the real step of the program, KKBPK is expected the welfare of the community will be better.

Correspondingly, in strengthening the KKBPK Program of 2015-2019, the President of the Republic of Indonesia entrusts BKKBN to arrange an activity or program that can strengthen the effort in achieving the target of the Development of Population and Family Planning Control 2015-2019, becomes the icon of BKKBN, also directly touch and provide benefit to the Indonesian at all levels of the region. In this case, it has been agreed that BKKBN was able to form Kampung KB.

Kampung KB becomes one of the strategic innovation to implement the activities of KKBPK's priority program as a whole in the work field. Based on BKKBN (2017), Kampung $\mathrm{KB}$ is one form/miniature models of the total implementation of KKBPK's program that involves all sectors in BKKBN and has synergy with the Ministry/Agency, partners, stakeholder related to the agencies appropriate to the needs and region condition, and implemented in the lowest level of government (appropriate to the prerequisite of Kampung KB's location determination) in all of regencies and cities. Through Kampung KB, it is expected to reduce the problem of poverty, access to health, and the concept that can be achieved a happy prosperous family (Wulantari, 2017).

There have been many studies on Kampung KB including Widodo \& Anam (2019); which aims to find out Kampung KB activities in increasing the effectiveness of the KB program. Furthermore, Syamsul, Mediansyah \& Pakaya (2019) examined the study of increasing family income through the UPPKS Kampung KB program. Meanwhile, this study is different from the previous study. In general, this study aims to determine the implementation of Kampung KB in Central Java. Also, the specific purpose of this study is to find out the input, process, and output in the implementation of Kampung KB as one form of improvement program KKBK in Central Java. Similar to this study, research on the evaluation of Kampung KB was also carried out by Zuhriyah, Indarjo 7 Ruharjo (2017) research because this study population is wider, namely the Central Java region. Meanwhile, from research purpose, which is about evaluating the implementation of Kampung KB every activity needs to be evaluated to find out its strengths and weaknesses as a basis for further action. Thus, this research needs to be done to evaluate what has been done by all fields in the representative environment of BKKBN Central Java province, synergize with partners, stakeholders related agencies to know its advantages and weaknesses as the basis for the next action. 


\section{METHOD}

This study used a qualitative approach to obtain the depth information about the input, process, output, implementation, monitorization, evaluation, and report, also an indicator of the success of Kampung KB involved various inter-sectors, local government, religious leaders and community leaders (Tokoh Agama/Tokoh Masyarakat), manager of Kampung $\mathrm{KB}$, and people participation. The data collection conducted by the depth interview with various informants such as Head of Representative and Head of Representative Division of BKKBN Central Java Province, The Regional Organization of Family Planning (OPD-KB), Partners from related sectors (Bappeda, Population and Civil Registry Office, District Health Office, District Education and Culture Office, District Environment, District Settlement Service, District Public Works Agency, and other inter-sectors related to Kampung KB's programs in each regency (Head of Kampung KB, Head of PKK at the level of the village, Community Leaders / Religious Leaders in the village / sub-district and sections), Kecamatan Device Cadres, Village / Sub-District, and RW (Head of Sub-district, Head of Village / Village Head, Head of RW, Head of RT, Head of Kampung KB).

The location of the study is selected purposively by considering the representation of the area including Magelang, Sukoharjo, and Temanggung. The data collection is conducted through primary data analyzed by processing the interview transcript data of informants.

\section{RESULTS AND DISCUSSION}

\section{Description of Location of the Study in Province}

Central Java is a province in Indonesia located in the central of Java. Administratively, it consists of 29 regencies and 6 cities. The regencies and cities' administration consists of 545 subdistricts and 8.490 villages. The population of Central Java is 32.382 .657 in 2010, consisted of 16.091 .112 of male and 16.291.545 of the female; or in the sex ratio of 98.8. This amount is lower than the projected population in 2010 which is 33.09 million, while the population growth rate is $0.37 \%$ per year that this is the lowest at the national level of $1.49 \%$ per year. The ratio dependency/dependence figure is 50.31 which is lower than the national 51.33 , with the population density is 995 people per $\mathrm{km}^{2}$ that is higher than the national 124 people/ $\mathrm{km}^{2}$, almost $14 \%$ Indonesian are in Central Java.

Profile of Kampung $K B$ in Magelang. Kampung KB Sanggrahan Legok/RW 9 is located in Wates village of North Magelang. Administratively, it is divided into 6 RT and becomes the area of population density about 436 people consisted of 221 men and 215 women with a total of 150 families. The number of Women of childbearing age (Wanita Usia Subur/WUS) is 104 and 68 Couples Age Fertile (Pasangan Usia Subur/PUS).

Profile of Kampung KB in Sukoharjo. Kampung KB Klampisrejo is located in Sidorejo village, a subdistrict of Bendosari which border to Pandeyan village, a subdistrict of Grogol with the population of 324 people consisted of 166 men (51.23\%) and women $158(48.77 \%)$ with a total of 116 families. Klampisrejo is a slum area that there are village grave, water puddles, creek, fences, and poorly groomed plants. Although the percentage is not much, some people have not been able to fulfill their primary, secondary, and tertiary needs (poor/pre-prosperity). The number of Couples Age Fertile (Pasangan Usia Subur/PUS) is 58 couples.

Profile of Kampung KB in Temanggung. Kampung KB Kencana Mandiri is located in Genayan village which included in Tawangsari village, a subdistrict of Tembarak, Temanggung. There are 2 RT in the village of Genayan with 314 people consisted of 164 men and 154 women with a total of 87 families. The number of Couples Age Fertile (Pasangan Usia Subur/PUS) is 58 couples. 


\section{Result of the Study}

The result of this study including an interview with the informants as the representative of BKKBN of Central Java; Magelang, Sukoharjo, and Temanggung. The result of the interview includes the input, process, and output aspects. The process of establishing the Kampung KB at the province level through the Governor's instruction, and regent's decree if it is in regency level. In relating to the Family Data in 2015, the data used to establish Kampung KB such as the regular statistic data, for example, KB participants, Couples Age Fertile, farmers, Penyuluh Keluarga Berencana (PKB), Penyuluh Kesehatan Lingkungan (PKL), as well as maternal mortality rate. Besides the data in 2015, it was able to use BPS or SDKI data. The fund to establish and implement Kampung KB sourced from the Anggaran Pendapatan Belanja Nasional (APBN), Anggaran Pendapatan Belanja Daerah (APBD), Dana Alokasi Khusus (DAK), and Anggaran Dana Desa (ADD). It could also use CSR funds, even the people's dues if needed.

In relating to the existence of POKJA in Kampung $\mathrm{KB}$, not all informants knew definitely about the working groups in each regency or city. The principle of the informants stated that the implementer team of Kampung KB, such as OPD KB and PLKB, have a good commitment related to the activities and inter-sectors cooperation to realize the Kampung $\mathrm{KB}$. From the aspect of the activity, informants understood various activities carried out in Kampung KB, for example, giving information about family planning (Keluarga Berencana), Tri Bina, PIK-R, Posyandu, also UPPKS founding. The funds for the establishment and implementation of Kampung KB sourced from State Budget (APBN), Regional Budget (APBD), Specific Allocation Fund (DAK), and Village Fund Budget (ADD), also CSR if it was possible, even the people's dues if needed. In relating to the facilities and infrastructure, each OPD KB has operational vehicles, such as KB information car, KB service car. Also, various KIE media provided in leaflets, banners, backdrops, or flipcharts. For the UPPKS development conducted by TTG (Teknologi Tepat Guna), like the supply of oven or laundry machine.

Each region held a workshop or training for about 5 days for the Kampung KB's team in the training hall such as in Banyumas, Ambarawa dan Pati. The materials presented related to the Kampung KB. The informants stated that the implementer team (POKJA) at the provincial and regency level to support the existence of Kampung KB. All informants were less understanding of the Kampung KB's activities related to the gathering with society. According to the interview with the informants who explained that BKKBN monitored the Kampung KB's activities, but each informant did not have a definite monitoring schedule. Related to the evaluation, it has not been conducted, it is monitorization only. Kinds of activity in Kampung KB include KKBPK and inter-sectors' activities. KKBPK's activities such as collecting data of R1KS (Couples Age Fertile and contraception data used), Tri Bina consists of BKB, BKR, and BKL, also UPPKS, PIK-R, and giving information about family planning. Inter-sectors' activities such as training, distributing seed and constructing infrastructure.

The informants did not understand in detail about raising the achievement of KKBPK's programs since it was under the ADPIN's responsibility. Kampung KB's programs need to be upgraded so that they became the superior program of kampung KB. The outcome of the programs was the existence of family planning service, Tri Bina, new family planning participants, and PIK-R. Most informants did not understand in detail about raising the achievement of inter-sectors' programs since it was under the ADPIN's responsibility. The head of ADPIN stated that connection with the inter-sectors, BKKBN has made a partnership with several offices such as the Health Department, Public Works Service, and Education Department.

The base of establishing Kampung KB was SK Walikota Magelang No. 477/152 Tahun 2016. To succeed in the programs, many cadres were recruited such as BKB, BKR, and 
BKL. The establishment of Kampung KB in Magelang was based on the family data in 2015 by using provincial funds in the amount of Rp. 20.000.000,- while OPD KB has not budgeted to establish Kampung KB. In 2018, OPD KB allocated Rp. 15.000.000,- for each Kampung $\mathrm{KB}$ as it was included in the strategic plan. The people there also collected dues for about Rp. 10.000,- /family every month for Kampung KB's activities in Sanggrahan Lor, Magelang.

The inter-sectors' cooperation in Kampung KB Sanggrahan Lor, Magelang such as Health Department through toddlers weighing program, 'waste bank' with environmental services Department, Education Department, civil registration, Bappeda. The work team of Kampung KB involved at a sub-district level such as Head of Sub-district, Head of Village / Village Head, Religious Leaders in the village (Pemuka Agama), PLKB, PKK Cadres, Health Cadres, Community Leaders, also UPPKS. Several inter-sectors were committed to guarding the planning of OPD to work on Kampung KB, for example, District Environment, Population and Civil Registry Office, also Education Office. In relating to the budgeting issue, the intersectors agencies have not provided specific allocation for Kampung KB's activities. Budget related to the Kampung KB's activities such as 'waste bank' conducted by District Environment through facilities and infrastructure supply, and Health Office who was conducted family planning services. In relating to the facilities and infrastructure, there were KIE media used but this inter-sectors' support was still at a minimum.

Together with the related government officials, OPD, Cadres, Community Leaders, which conducted twice a year, with the socialization of Kampung KB as the material. However, it was not specifically used or conducted for Kampung KB's activities. Generally, they got the socialization in twice. According to the interview with the informants from the inter-sectors officials, it was known that there was a routinely POKJA meeting at the regency level. Village apparatus, cadre, and village administrators hold the routine POKJA meeting once a month. The material discussed depends on the topic needed such as implementing the mass family planning place, screening, sharing of knowledge, reporting the Couples Age Fertile membership, and so forth. The most difficult to be conducted was the activity that involves teenagers.

Gathering with society was also conducted once a month, but it was not specifically discussed about kampung KB. The material discussed depends on the topic needed such as the official information, PLKB advice, the appeal for society to do MOW, free programs, and problems experienced by cadres. Provincial BKKBN and regency OPD monitors in every three months coordinated by ADPIN. They monitored physical and administrative activities. Provincial BKKBN required the OPDKB report related to the implementation of the program in each regency. When OPDKB conducted monitoring, evaluating the Kampung $K B$ in society so that there would be recording and reporting the Kampung KB activities.

Kinds of activity conducted in Kampung KB such as KKBPK and inter-sectors activities. The KKBPK activities were R1KS, Tri Bina consisted of BKB, BKR, and BKL, UPPKS, PIKR, giving information about family planning, giving information to the teenagers about the dangers of the drug, character education, elderly gymnastic, health checking, recitation, and landfill. While, the inter-sectors activities were conducted by District Environment such as giving information about sanitation, eradicating the mosquito nest, toddler, and elderly family-planning services. Ministry of Religion also conducted counseling for society.

Nowadays, in each sub-district in Magelang has Kampung KB. These Kampung KB brought some changes to society, such as the awareness of keeping the environmental hygiene, the improvement of women's' creativity, the prevention of various juvenile delinquency, the improvement of society's participation to do the family planning program, and better infrastructure.

Since all of the inter-sectors have not committed to conduct Kampung KB, the programs' achievement was also not optimum. The base of establishing the Kampung KB was SK Bupati No 476/948/Tahun 2016. The criteria for establishing Kampung KB in Klampisrejo 
were slum area, near the railway, and economic status that has not prosperous yet. PK data in 2015 was used in establishing Kampung KB such as the level of KB participation, PUS, teenagers, new, and active KB's achievement. The fund sourced from Province about Rp. 15.000.000,- People who were in the prominent economy also donated; furthermore, the fund was given from the APBD.

Inter-sectors were attempted to involve in Kampung KB of Klampisrejo's activities such as Bappeda, District Health Office, District Education Office, District Environment, Population and Civil Registry Office, District Housing and Settlement Office, and District Social Office. While, work team of Kampung KB in Klampisrejo that were attempted to involve in Kampung KB such as Head of Sub-district, Head of Village, PLKB, Health Cadres, Head of PKK, Religious Leaders (Tokoh Agama), Community Leaders, BKB, BKR, BKL, PIK-R, and UPPKS sections.

Several inter-sectors who has committed to guiding OPD's planning to implement Kampung KB were still lack of support, such as, District Health Office, District Environment, Population and Civil Registry Office, also District Social Office. The availability of funds/budget that there was no specific budget to implement Kampung KB. In each village and sub-district, there was support to establish cooperative including the Kampung KB area, so that it was expected that women especially mothers have financial capital. Village apparatuses, cadre, and Kampung KB officials they have been getting the socialization of Kampung KB about twice. The training participants were inter-sectors related to the programs such as Bappeda, District Health Office, District Environment, Population and Civil Registry Office, District Social Office, District Education Officer, and District Housing and Settlement Service Office with the training materials about technical guidance of Kampung KB, Kampung KB's activities, inner-sectors coordination, Tri Bina, and PIK-R.

The data used in establishing Kampung KB was the data from family data collection in 2015. Besides that, the other data were also used such as BPS and SDKI about health and welfare. There was no routine meeting in the POKJA of Kampung KB at the regency level. However, all the village apparatus, cadre, and Kampung KB officials have monthly POKJA The head of the citizen also gave socialization about Kampung KB to society. The meeting was conducted once a month with the meeting material discussed in gathering, it also depended on the topic needed.

The monitoring conducted by BKKBN Province was not scheduled. Every month the BKKBN also requests the OPD KB report to what extent the Kampung KB implements the programs, while the inter-sectors related to the programs such as District Social Office monitors at a particular area every three months. In each Kampung KB evaluation, there would be the Kampung KB's recording and reporting.

Kinds of activity conducted in Kampung KB including KKBPK activities such as Tri Bina (BKB, BKR, and $B K L)$, UPPKS, PIK-R, giving information about family planning, giving information to the teenagers about the dangers of the drug, character education, elderly gymnastic, health checking, recitation, and landfill. While, the inter-sectors activities, for example, a breeding activity about how to do the duck livestock training, the use of empty land; District Social Office about eradicating the mosquito nest, and examining the mosquito larva. In relating to the achievement of KKBPK's program has not been fully conducted. The existence of Kampung KB led many directed and useful activities; teenagers included. The people's knowledge and participation to join family planning also raised. By the existence of $B K L$, elderly gymnastics, and health checking, the elderly looked healthier.

In the case of raising the achievement of the inter-sectors' program, not all of the intersectors were committed to Kampung KB, the result was also less of maximum. The base of establishing Kampung KB in the Temanggung Regency was Surat Edaran (SE) dan Surat Keputusan (SK), but the informants could not mention the SE and SK numbers. They stated 
that there was no technical guidance in Temanggung regency. During this time they were guided by the provincial leaflet entitled "Juknis Pembentukan Kampung KB".

The system used in this regency was the bottom-up system that Head of Village hold activity and proposed the budget to the regency. The people of Tawangsari village at Kampung KB Kencana Mandiri used their dues although it has been informed that there was ADD (Anggaran Dana Desa) fund about Rp. 10.000.000,- per year.

POKJA in Temanggung regency has not been established yet, while at the subdistrict/village level it has been established. Related to the inter-sectors, they used an integrated process, if there was any activity proposed at the village level, all inter-sectors would support it. The inter-sectors who have been involved in Kampung KB activities were OPD such as District Health Office, District Agriculture Officer, and District Education Office. Head of Village / Village Head, PLKB/PKB as the counselor (by SK), and cadres who directly involved in establishing and exiting the Kampung KB in Temanggung Regency.

The commitment of inter-sectors in Temanggung regency has not been running properly. District Public Works Agency of Temanggung admitted that they have never participated in any socialization such as workshops or meetings related to the Kampung KB. Population and Civil Registry Office in Temanggung has not been involved in the Kampung KB's programs, nor the District Social Office. While, District Health Office, Bappeda, District Education Officer, and Dinpermasdes were better than others that they have attended the socialization of Kampung KB's programs hold the province, at least once. Regardless of the issue above, all the OPDs stated their willingness to engage in activities related to the Kampung KB which integrated by a village that proposed it.

The Kampung KB's activities in Temanggung have been using ADD in the amount of Rp. 10.000.000,- per year for the activities and administrative operations. However, that fund was not enough, people used their dues. Providing human resources was kind of the facilities and infrastructure support given, if there was a research locus would hold an activity that required family planning information and service car, then it would be pursued for one day of the Kampung KB's activity. Likewise for banners, leaflets, flipcharts, backdrops, and others. Yet, the inter-sectors' adjuvant and related facilities have not been realized.

OPD, Kadin, Cadres, and Community Leaders have attended the training/socialization hold by Province or Regency, at least once. Although there were some agencies claimed that they have never attended it such as District Social Office and Population and Civil Registry Office. The training material like information about family planning, inter-sectors coordination, and economic empowerment. The data used in the process of establishing Kampung KB were the data of participants who have not joined the family planning program, early marriage data, number of $\mathrm{KK}$, and demography which generally obtained from the PK data in 2015. At the level of sub-district/village, the establishment of a work program has been conducted as the routine meeting-minimally every 35 days which simultaneously with the people's routine meeting. The material discussed were activities that can improve the people's economy from toddlers, adolescents to the elderly, also about the existing problems and conditions.

The socialization or gathering about Kampung KB conducted once a month which simultaneously with the people's routine meeting. There was no inter-sectors' involvement directly in the gathering activity. The material discussed such as the development and difficulty of Kampung KB, but it mostly becomes one meeting with the other agenda like RT meeting. Since the OPD KB in Temanggung Regency has not been directly involved in Kampung KB's programs, thus there was no monitoring, evaluating, recording, and reporting that could be explained.

There were 39 Kampung KB in Temanggung, one of them was in Tawangsari Village named Kampung KB Kencana Mandiri. The activities implemented were libraries, BKB, BKR, 
BKL, PIK-R, learning guidance, and UPPKS. While, the activities of inter-sectors are corn seedling, drainage, privies, and home industry training. The positive effects of the Kampung KB were the improvement of the people's economy although it was not significant. The unemployed people, now they have positive activities such as joining gymnastics for the elderly and home industry training for the housewives. One kind of several inter-sectors' attention was the existence of drainage. Physically, the village became cleaner and healthier. Also, it could monitor the early marriage and the rate of the school drop out became lower.

\section{Discussion}

The success of Kampung KB was viewed according to the input, process, and output aspect. Related to the input, particularly the conformity of establishing the Kampung KB; for example in Central Java that it referred to the criteria in the technical guidelines. Kampung KB "Kencana Mandiri" in Tawangsari Village, Temanggung Regency with the criteria such as the number of poor families (Pra-KS and KS-1) and the condition of the people who were in unconsciousness to participate in the family planning program; Kampung KB "Klampisrejo" in Sukoharjo Regency with the criteria such as slum area, near the railroad, and none prosperous economy; Kampung KB "Sanggrahan Legok" in Magelang with the criteria such as slum area and population density.

The local Government and inter-sectors participation and commitment in establishing and implementing Kampung KB, the OPD KB was highly committed. It is as revealed in the study of Bachtiyar \& Wibawani (2017) that the PLKB has been functioning properly, namely always ready and responsive to serve the community to participate in the Kampung KB program. On the other hand, the inter-sectors have not fully committed. The inter-sectors worked based on their job descriptions. According to Rahmeina (2018), this is because advocacy to cross-sectoral is still minimal, which has an impact on the lack of support of related sectors. Also, each sector in just running its programs itself.

This condition is in line with these studies; (Normajatun, Malawat \& Fibriyanita, 2018; Saputra, et.al., 2019) that the inhibiting factors for the implementation of Kampung KB are the funds/budget, the attitude of implementers, in this case, the attitude of the members of related agencies and the economic environment. The same result was also found in the study of Syamsul, Mediansyah \& Pakaya (2019) that the government and cross-sector support in the effort to empower families was not maximal yet, particularly in UPPKS Kampung KB program. Another thing is the lack of cooperation between human resources that run it (Nurjannah Susanti, 2018). This condition because the key to the success of Kampung KB is the coordination of all parties both government, private, and community (Rahmeina, 2018).

While the support in facilities and infrastructure was less optimum. There were some facilities provided by the people themselves such as room/building/hall/tent/table and sound system. Also, human resources were the most important of the adjuvant factor in Kampung KB's programs. Resource Facilities play an important role in supporting and support the implementation of the KB village Program. Facilities, in this case, is a facility and infrastructures that deserve to support the success of the Kampung KB program (Istiadi Rosdiana, 2012).

According to Merrynce (2013), the dominant factors affect the effectiveness of implementing the Kampung KB's programs are communication and resource factors. In line with the result of the study of Normajatun, Malawat \& Fibriyanita (2018) it is known that the supporting factors in the implementation of Kampung KB are human resources, facilities/infrastructure, and information resources (socialization and counseling carried out by related agencies). 
The reality in this study is known that PLKB as the human resource was still in lack; ideally, one PLKB handled two villages, but in the reality that one PLKB handled at least three villages. This condition related to the study of Zuhriyah, Indarjo \& Raharjo (2017); Widodo \& Anam (2019); (Saputra, et.al., 2019) that technically the number of cadres working in the field is not appropriate because there are officers who concurrently perform other tasks.

Related to the process, the data utilization sourced from the family data in the Kampung KB area known as the data used by all of Kampung KB in Central Java in 2015. The data included data of the people who have not joined family planning, early marriage, Couples Age Fertile, the achievement of the new and active KB's participants, low KKBPK data, low ASFR data, Tri Bina or PIK-R, also the demographic area. Temanggung Regency had the highest early marriage data; in which there was $60 \%$ of the married couple below 20 years old.

Meanwhile, the founding and mobilization by the program manager of provincial Kampung KB have not been routinely scheduled and fully coordinated. Similarly, at the regency and research locus level, the founding was also less of maximum. It means that the coordination at the level of provincial or regency was not implemented well. For example, PLKB in Temanggung Regency claimed that they have attended the socialization/training at Balai Diklat of Ambarawa for four days, whereas PLKB in Sukoharjo Regency has not attended a similar activity. Coordination was the most important thing for program sustainability and success. This is as stated by Herujito (2001) that coordination is an orderly arrangement of an effort association or alliance to be united in achieving common goals. Furthermore, Manullang (2008) argues that coordinating is a function of management to conduct various activities so that there is no chaos, quarrel, or gap activities by connecting, unifying, and aligning subordinate works to get the directed cooperation in achieving the organizational goals. Therefore, coordination is the most important thing in the organization.

Besides that, people's knowledge and participation related to the Kampung KB's activities and programs were also less of a maximum. This condition was also found based on the study by Nurjanah and Susanti (2018). In line with that, according to Nurhajadmo (2008) states that a good understanding of the program will affect the policy implementer's attitude. Delivering inappropriate information from the upper-line to establish Kampung KB caused chaos. As a result, the team of Kampung KB such as PLKB, cadre, Religious Leaders, and Community Leaders were confused about the Kampung KB's concept. The people participating in the research locus was so high. They always expect the programs/activities from the local government and inter-sectors. The collaboration of regency/city government, village government, CSO, private sector, and society is a major force impacting this program which can achieve the objectives as stipulated (Yunas Nailufar, 2019).

Furthermore, related to the output were kinds of activity in Kampung KB. The activities that have been conducted such as Tri Bina (BKB, BKR, BKL), UPPKS, PIK-R, learning guidance, and libraries. While, the inter-sectors' activities such as drainage, privies, corn seedling, 'waste bank', home industry training, duck livestock training, and infrastructure improvement. Meanwhile, the achievement of program indicators in Kampung KB area was found that KKBPK's program has not been completed, despite bringing a little change to the welfare of the people. This condition was also found in the result of Zuhriyah, Indarjo \& Raharjo (2017) research. Nevertheless, the results of this study are also known to at least bring a slight change in people's welfare. The people's knowledge and participation to join family planning also increase. By the existence of BKL, the elderly gymnastic and health checking helped them to be healthier. Besides, PIK-R was used by teenagers to create positive activities. Also, Mardikanto \& Soebiato (2015) stated that empowerment is defined as an effort to improve the community's capacity (poor, marginal, or outskirts) to convey their 
opinion or need, also choices to participate, negotiate, influence, and manage the institution accountably for a better life.

\section{CONCLUSION AND SUGGESTION}

According to the result and the discussion, it could be concluded that relating to the input known that the establishment of Kampung KB was appropriate to the Kampung KB technical guidelines. The government participation and commitment to implementing Kampung KB's programs were quite good, but the inter-sectors participation and commitment were not as good as the government. The facilities and infrastructure to support Kampung KB in Central Java were still quite low. In this case the construction of the Kampung KB gateway as the implementation and development of Kampung KB. About the process, it could be concluded that the data sourced from the Family Data in 2015. The founding and mobilization by the manager of Kampung KB at the Provincial level have not been routinely scheduled and fully coordinated. The people's participation related to the Kampung KB activities were good enough. In relating to the output, it could be concluded that the kinds of Kampung KB activities were Tri Bina (BKB, BKR, BKL), UPPKS, PIK-R, learning guidance, and libraries, while the inter-sectors' activities such as drainage, privies, corn seedling, 'waste bank', home industry training, duck livestock training, and the infrastructure improvement. Concerning to the achievement of KKBPK's programs has not been completed, despite bringing a little change to the welfare of the people.

According to the result of this study, it could be suggested several things as follows: For the policymakers: (a) The socialization of Kampung KB to the local government or society should be conducted by the competent people who know exactly about Kampung KB. (b) It is necessary to design and realize the budget for the implementation of Kampung KB. (c) It is necessary to make SK of Kampung KB appropriate to the regional criteria entitled "SK Kampung KB". (d) The clarity of the Kampung KB implementer about their main function should be clear. (e) The President must give direct instruction to strengthen the implementation of Kampung KB which involves inter-sectors. For the Head of Representative of BKKBN Province: (a) It is necessary to coordinate with the subordinate. (b) The appropriate strategy and communication in implementing Kampung KB are necessary. For the Head of Representative of BKKBN Province and OPD-KB, it is necessary to provide the based multimedia of KIE to attract people, for example, website. For the OPD KB, it is necessary to make social media (Facebook, Twitter, or Instagram), also make data digitally or online so that it can be accessible by the inter-sectors to conduct many programs in Kampung KB. For the District Builder, it is necessary to maximize the responsibility in his area. For the inter-sectors OPD, cooperation and commitment need to be increased. For the Team of Kampung KB implementer, it is necessary to arrange a standardized report of Kampung KB activities so that it will be more systematic. And, for human resource development, many pieces of training, workshops for the Kampung KB human resource should be arranged such as improving the capacity of Village Head and PLKB.

\section{REFERENCES}

Bachtiyar, N. A. \& Wibawani, S. (2017). Implementasi Program Kampung Keluarga Berencana di Dusun Ambeng-Ambeng Desa Ngingas Kecamatan Waru Kabupaten Sidoarjo. Jurnal Dinamika Governance FISIP UPN “Veteran” Jatim, 7(1), 13-26.

BKKBN. (2014). Pedoman Pelaksanaan Penggerakan Lini Lapangan Program Kependudukan, Keluraga Berencana dan Pembangunan Keluarga Tahun 2014. Jakarta: Direktorat Bina Lini Lapangan.

BKKBN. (2017). Petunjuk teknis Kampung KB. Jakarta: Direktorat Bina Lini Lapangan. 
Herujito, Yayat M. (2001). Dasar-dasar manajemen. Jakarta : PT. Bumi Aksara.

Istiadi, A. \& Rosdiana, W. (2012). Implementasi Program Kampung Keluarga Berencana (Studi pada Kelompok Sasaran Keluarga Dengan Remaja di Dusun Waung Desa Sonoageng Kecamatan Prambon Kabupaten Nganjuk). Publika, 5(4), 1-8.

Lahijani, P. (2012). Human resoures empowerment strategies in development projects. International Journal of Engineering Researcch and Apliations (IJERA), 2(3), 2760-2761.

Manullang, M. (2008). Dasar-Dasar Manajemen. Yogyakarta: Gajah Mada University Press

Mardikanto, T., Soebiato, P. (2015). Pemberdayaan masyarakat dalam persepektif kebijakan publik. Bandung: Alfabetha.

Merrynce, H. A. (2013). Efektivitas pelaksanaan program Keluarga Berencana. Jurnal Kebijakan Publik, 4(1), 1-118.

Normajatun, Malawat, S.H., Fibriyanita, F. (2018). Implementasi kebijakan program kampung keluarga berencana - Kampung Baiman (KKB-KB) di Kota Banjarmasin. As Siyasah, $3(2), 1-4$.

Nurharjadmo, W. (2008). Evaluasi implementasi kebijakan pendidikan sistem ganda di sekolah kejuruan evaluation implementation dual system education program in Senior Technical High School. Spirit Publik, 86(4), 215-228.

Nurjannah, S.N. \& Susanti, E., (2018). Implementasi Program Kampung Keluarga Berencana (KB) di Kabupaten Kuningan Tahun 2018 (Studi Kuantitatif Dan Kualitatif). Jurnal IImu Kesehatan Bhakti Husada: Health Sciences Journal, 9(2), 78-85. DOI: https://doi.org/ 10.34305/jikbh.v9i2.64

Rahmeina, F.R. 2018. Koordinasi dalam Program Kampung KB di Kota Pekanbaru. JOM FISIP, 5(1), 1-12

Saputra, Y.W., Lukas, Titin, Rindanty, R.S., (2019). Implementasi Program Kampung Keluarga Berencana (KB) di Kota Samarinda. Jurnal Georafflesia. 4(2), 186-200

Syamsul, Mediansyah, A.R., \& Pakaya, S. (2019). Kajian peningkatan pendapatan keluarga (Studi pada program UPPKS Kampung KB Kelurahan Dulalowo Kota Gorontalo). Jurnal Economic Resources, 2(1), 76-85.

Widodo, M.N. Anam, M.K., (2019). Kampung Keluarga Berencana dalam peningkatan efektivitas program Keluarga Berencana di wilayah Cilenggang. Prosiding Seminar Nasional Pengabdian Masyarakat LPPM UMJ. Website: http://jurnal.umj.ac.id/ index.php/semnaskat.

Wulantari, R.A., (2017). Kampung KB dalam Bingkai Media: Analisis Framing terhadap Pemberitaan Kampung KB selama Tahun 2016. Demography Journal of Sriwijaya (DeJoS), 1(2), 11-16.

Yunas, N. S., \& Nailufar, F. D., (2019). Collaborative Governance melalui Program Kampung KB Di Kabupaten Jombang. CosmoGov: Jurnal IImu Pemerintahan, 5(2), 162-173.

Zuhriyah, A., Indarjo, S., \& Raharjo, B.B., (2017). Kampung Keluarga Berencana dalam peningkatan efektivitas program Keluarga Berencana. Higeia Journal of Public Health Research and Development, 1(4), 1-13. 